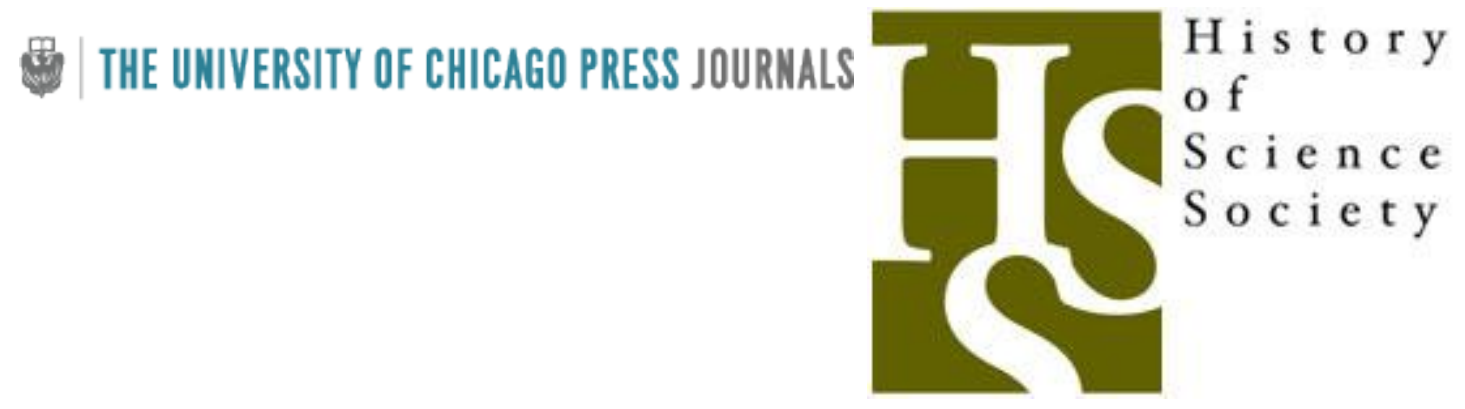

Science in the Everyday World: Why Perspectives from the History of Science Matter Author(s): Katherine Pandora and Karen A. Rader

Source: Isis, Vol. 99, No. 2 (June 2008), pp. 350-364

Published by: The University of Chicago Press on behalf of The History of Science Society

Stable URL: https://www.jstor.org/stable/10.1086/588693

JSTOR is a not-for-profit service that helps scholars, researchers, and students discover, use, and build upon a wide range of content in a trusted digital archive. We use information technology and tools to increase productivity and facilitate new forms of scholarship. For more information about JSTOR, please contact support@jstor.org.

Your use of the JSTOR archive indicates your acceptance of the Terms \& Conditions of Use, available at https://about.jstor.org/terms

The University of Chicago Press and The History of Science Society are collaborating with JSTOR to digitize, preserve and extend access to Isis 


\title{
Science in the Everyday World
}

\section{Why Perspectives from the History of Science Matter}

\author{
By Katherine Pandora* and Karen A. Rader**
}

\begin{abstract}
The history of science is more than the history of scientists. This essay argues that various modern "publics" should be counted as belonging within an enlarged vision of who constitutes the "scientific community" — and describes how the history of science could be important for understanding their experiences. It gives three examples of how natural knowledge-making happens in vernacular contexts: Victorian Britain's publishing experiments in "popular science" as effective literary strategies for communicating to lay and specialist readers; twentieth-century American science museums as important and contested sites for conveying both scientific ideas and ideas about scientific practice; and contemporary mass-mediated images of the "ideal" scientist as providing counternarratives to received professional scientific norms. Finally, it suggests how humanistic knowledge might help both scientists and historians grapple more effectively with contemporary challenges presented by science in public spheres. By studying the making and elaboration of scientific knowledge within popular culture, historians of science can provide substantively grounded insights into the relations between the public and professionals.
\end{abstract}

$\mathrm{H}$ ISTORY OF SCIENCE is more than the history of scientists: it is also the history of what "science" and "nature" mean to each one of us. For too many generations, the professional scientific community has slighted the significance of what happens outside the temple of science, in large part preferring to delegate contact with the public to others because they judge that engagement with nonprofessionals holds little value for practitioners. Nonetheless, when they do encounter science in the everyday world, scientists have been repeatedly dissatisfied to find that what happens in the public sphere is not

* Department of the History of Science, Physical Sciences Building 619, University of Oklahoma, Norman, Oklahoma 73019; kpandora@ou.edu.

** Department of History and the Science, Technology, and Society Initiative, Virginia Commonwealth University, Richmond, Virginia 23284; karader@vcu.edu.

The third member of our Woods Hole Working Group on Science and the Public was Bernard Lightman. We wish to acknowledge the importance of his leadership in the discussions that occurred both prior to and during the workshop and his role in helping us develop our thinking on these issues. 
simply a replication of their own priorities, interests, and values; they have been hardpressed to understand "the public mind," which at times can seem to them childish, shallow, superficial, emotional, irrational, and subjective- hardly a world to take seriously. From this standpoint, the idea that the public might be a partner in the scientific community seems an unlikely prospect. Taking cues from professional scientists, many generations of historians of science also considered science in popular culture to be too trivial a matter for highly trained researchers to take seriously: why would any ambitious scholar study what is a mere sideshow to the main event?

These attitudes have had serious consequences, including a disrespect for our fellow citizens. They have also prevented scientists and historians alike from understanding what the making and interpretation of natural knowledge looks like when it occurs "flat on its belly in the middle of experience," outside the confines of professional science, where investigations can be disciplined, standardized, and studied under controlled conditions. ${ }^{1}$ Science as it occurs within popular culture is not simply a more dilute, less sophisticated, error-plagued imitation of "real" science: it, too, is "real" science, in the encompassing sense that the "scientific imagination" belongs not only to scientists and their realms of expertise but (much like C. Wright Mills's "sociological imagination") also to ordinary people and everyday circumstances. ${ }^{2}$

Likewise, when historians and scientists alike categorize as scientific participants only those who make a living as professionals, we miss the "unofficial" experiences of "science in the vernacular," which have consequences that reverberate in individual lives as well as throughout the wider culture. ${ }^{3}$ These experiences include such seemingly trivial and ephemeral activities as puzzling over the view through a kaleidoscope and making pilgrimages to natural history museums and aquaria; watching Bill Nye, the Science Guy and Japanese monster movies; observing the proliferation of forensic scientists on tele-

1 The phrase "flat on its belly in the middle of experience" is from William James, A Pluralistic Universe (1909; Cambridge, Mass.: Harvard Univ. Press, 1977), p. 125; James is expressing his dissatisfaction with the "thin" empiricism of philosophies that are out of touch with experiential realities. A compelling argument about what happens when "our fellow citizens" are forgotten by professionals has been made about historians by David Thelen: "the greatest danger from professionalization-a danger that is great because it is often invisible-is that its self-enclosing thrust has made it harder for us professionals to recognize which of our practices resemble 'common,' 'local,' or 'everyday' knowledge and perspective and which have evolved into jargon that makes sense only to other professionals. If we wish to construct serious dialogues about the past with nonprofessionals - who are, after all, our fellow citizens and human beings - we may need to go back and revalue our first languages, the ones we were taught to leave behind when we entered the professional world. By recognizing patterns in our history-making practices that we share with others, we can more effectively contribute to the larger historical culture we all inhabit." David Thelen, "Afterthoughts: A Participatory Historical Culture," in Roy Rosenzweig and Thelen, The Presence of the Past: Popular Uses of History in American Life (New York: Columbia Univ. Press, 1998), pp. 190-207, on p. 191.

2 Gerald Holton's notion of the "scientific imagination," introduced in the late 1970s in The Scientific Imagination: Case Studies (Cambridge: Cambridge Univ. Press, 1978), aimed to address how understanding the way scientists think about their work could have practical implications for the history and philosophy of science, for science education, and for the larger understanding of the place of science in our culture. But Holton did so through a detailed analysis of case studies of prominent scientists, showing how for each the "role of personal motivations" shaped their ideas and theories. What we have in mind is more akin to Mills's late-1950s preoccupation with the experience of social alienation and his emphasis that "neither the life of an individual nor the history of a society can be understood without understanding both": C. Wright Mills, The Sociological Imagination (London: Oxford Univ. Press, 1959), p. 3. Neither the life of science nor the history of science in society can be understood without understanding both, and we as historians risk alienating further generations of scientists from the field if we do not write stories that explore the dynamics of the scientific imagination more broadly.

3 See Katherine Pandora, "Knowledge Held in Common: Tales of Luther Burbank and Science in the American Vernacular," Isis, 2001, 92:484-516. 
vision and significantly revised displays of dinosaur skeletons in natural history museums; or having conversations (in school classrooms, around dinner tables, and on internet blogs) about what we think might be "out there" when we gaze into the night sky.

Understanding how knowledge-making happens in these contexts, what it means, and what the consequences are can help us grapple more effectively with the challenges presented by science in public — challenges such as tension over the right relationship between scientific elites and the wider polity, or how religion is characterized in the mainstream media as being "at war" with evolutionary science, or the politics of debates over global climate change or stem-cell research, or why a junior high school student decides that he or she is-or is not-a "science person." The consequences of these discussions and experiences receive wider attention when they have broader policy implications - as when the local school board in Dover, Pennsylvania, presented evolution as "just a theory" in its biology curriculum. But there is a much wider field of resonances within which these "sensational" events are embedded, and to ignore the field and focus only sporadically on the flashpoints gives one limited traction in working with the dynamics involved.

What is typically characterized as "science and popular culture" is often given only superficial attention by both scientists and historians because it is presumed to be inconsequential in the production of knowledge. ${ }^{4} \mathrm{~A}$ still-dominant picture of knowledge production in the history of science fits what Stephen Hilgartner has termed the "two-stage model": first scientists create genuine knowledge; then popularizers disseminate a watered-down version to a "sponge-like," passive public. Science studies scholars tagged this presumed dynamic and its variants with several names-such as the "diffusionist model" and the "deficit model"- and have shown how (as Hilgartner originally argued) "this view of popularization grants scientists broad authority to determine which simplifications are 'appropriate' (and therefore usable) and which are distortions (and therefore useless-or worse!)." ${ }^{5}$ As Nancy Tomes has recently argued, "policymakers and historians tend to ignore trends in popular culture as annoying or irrational distractions, yet these trends constitute a powerful source of information" about how different publics constitute natural knowledge. ${ }^{6}$

That said, the history of science and popular culture is far from virgin scholarly

\footnotetext{
${ }^{4}$ As one heartfelt example of this view see Douglas R. Hofstadter, "Popular Culture and the Threat to Rational Inquiry," Science, 1998, 281:512-513. Important work in explicating these tensions over the last two decades has been done by Bruce Lewenstein. See, e.g., Bruce V. Lewenstein, ed., When Science Meets the Public (Washington, D.C.: American Association for the Advancement of Science, 1992); Lewenstein, "What Kind of 'Public Understanding of Science' Programs Best Serve a Democracy?" in Science Studies: Probing the Dynamics of Scientific Knowledge, ed. Sabine Maasen and Matthias Winterhager (Munich: Transcript, 2001), pp. 235-255; and Lewenstein, "Models of Public Communication of Science and Technology," June 2003, http://communityrisks.cornell.edu/BackgroundMaterials/Lewenstein2003.pdf (accessed 24 Sept. 2007).

${ }^{5}$ Stephen Hilgartner, "The Dominant View of Popularization: Conceptual Problems, Political Uses," Social Studies of Science, 1990, 20:519-539, on p. 520. Cf. Alan Gross, "The Roles of Rhetoric in the Public Understanding of Science," Public Understanding of Science, 1994, 3:3-23; and Patrick Sturgis and Nick Allum, "Science in Society: Re-evaluating the Deficit Model of Public Attitudes," ibid., 2004, 13:55-74. See also the discussion in Jane Gregory and Steve Miller, Science in Public: Communication, Culture, and Credibility (New York: Plenum, 1998). Among the first-generation histories of science and popular culture, John C. Burnham's book, How Science Won and Superstition Lost: Popularizing Science and Health in the United States (New Brunswick, N.J.: Rutgers Univ. Press, 1987), stands out for its careful attention to the dynamic between science and popular culture; but that even Burnham poses his narrative as oppositional (science versus superstition) is telling.

${ }^{6}$ Nancy Tomes, "The Making of a Germ Panic, Then and Now," American Journal of Public Health, 2000, 90:191-198, on p. 196.
} 
territory-starting in about 1980, a growing number of historians of science have taken on the task of identifying, hypothesizing, analyzing, and debating the features that make up the contours of the field. The gathering of a critical mass was given wider notice roughly a half-generation ago, with Roger Cooter and Stephen Pumfrey's 1994 review article "Separate Spheres and Public Places: Reflections on the History of Science Popularization and Science in Popular Culture." In their painstaking survey of the contemporary currents of scholarship in this area, Cooter and Pumfrey argued that there had been many false starts but that much had been achieved in terms of the development of case studies and of a greater awareness of the complexities of the questions involved. Even still, they acknowledged, "once we leave the well-charted areas of learned science for popular science we are without a map." Cooter and Pumfrey argued that historians of science needed to address more carefully the uses of scientific popularizations by varied audiences, for "'popular science' may diverge from 'learned science,"” they suggested, "not because the latter is poorly understood, but because it is developed by its recipients for different purposes."

Starting from the premise that the interests of the scientific community and the investigations of historians of science and popular culture converge around issues of communication and the circulation of knowledge, we suggest that ignorance of what happens within the public sphere perpetuates exclusionary habits of mind that short-circuit engagement with science's most important epistemological, metaphysical, and ethical challenges and thereby limit the effectiveness of scientists as participants in public debates. We propose that by studying a community of scientific imagination that is larger and more diverse and that carries within it a wider body of experience than it has been traditional to consider, historians of science in popular culture could offer new ways of conceiving what "science for the people" might look like. ${ }^{8}$ By bringing into focus real-world paths between science and popular culture that have existed and exploring the rationales, ramifications, and cultural linkages that made traffic along them possible,

\footnotetext{
${ }^{7}$ Roger Cooter and Stephen Pumfrey, "Separate Spheres and Public Places: Reflections on the History of Science Popularization and Science in Popular Culture," History of Science, 1994, 32:237-267, on pp. 248, 250. Some pioneering works in this field include Cooter, The Cultural Meaning of Popular Science: Phrenology and the Organization of Consent in Nineteenth-Century Britain (Cambridge: Cambridge Univ. Press, 1984); Bruce V. Lewenstein, "Was There Really a Popular Science 'Boom'?" Science, Technology, and Human Values, 1987, 12:29-41; Lewenstein, "The Meaning of 'Public Understanding of Science' in the United States after World War II," Publ. Underst. Sci., 1992, 1:45-68; Greg Myers, "Science for Women and Children: The Dialogue of Popular Science in the Nineteenth Century," in Nature Transfigured: Science and Literature, ed. John Christie and Sally Shuttleworth (Manchester: Manchester Univ. Press, 1989), pp. 171-200; Myers, "Nineteenth-Century Popularizers of Thermodynamics and the Rhetoric of Social Prophecy," Victorian Studies, 1985, 29:35-66; Ann Shteir, "Botanical Dialogues: Maria Jacson and Women's Popular Science Writing in England," EighteenthCentury Studies, 1990, 23:301-317; James Secord, "Newton in the Nursery: Tom Telescope and the Philosophy of Tops and Balls," Hist. Sci., 1985, 23:127-151; Susan Sheets-Pyenson, "Popular Science Periodicals in Paris and London: The Emergence of a Low Scientific Culture, 1820-1875," Annals of Science, 1985, 42:549-572; Steven Shapin, "Science and the Public," in Companion to the History of Modern Science, ed. R. C. Olby et al. (New York: Routledge, 1990), pp. 990-1007; Jan V. Golinski, Science as Public Culture: Chemistry and Enlightenment in Britain, 1760-1820 (New York: Cambridge Univ. Press, 1992); Simon Schaffer, "Natural Philosophy and Public Spectacle in the Eighteenth Century," Hist. Sci., 1983, 21:1-43; and Harriet Ritvo, The Animal Estate: The English and Other Creatures in the Victorian Age (Cambridge, Mass.: Harvard Univ. Press, 1987).

${ }^{8}$ Science for the People was a U.S. political organization that emerged in the 1970s, from the Sociobiology Study Group at Harvard, and that took as its primary mission consciousness-raising about the dangers and misuses of science during the Vietnam War. But STP founder Herb Fox acknowledges that there was much dialogue about the many possible meanings of "science for the people"; see the open letter from Herb Fox at the Science for the People Web site: http://www.scienceforthepeople.com/modules.php?op=modload\&name= News\&file $=$ article \&sid $=21$ (accessed 7 Oct. 2007).
} 
historians of science can move beyond the often speculative information gleaned from what Jane Gregory and Steve Miller describe as "the much wielded but in some ways rather blunt instrument, the quantitative social survey.",

Humanistic inquiry - in the form of investigations into popular science from historical, literary, and philosophical perspectives-is imperative, if the stories and events that make up the sphere of popular culture are to be made accessible for discussion. Ultimately, we argue, what we stand to gain in traveling these paths and bringing our best analytical skills and investigative tools to bear on these journeys is not simply the possibility of scholarly enlightenment, but also the positive transformation of relations between expert scientific practitioners and nonexpert public science participants. Such histories would allow for a firmer grasp of what is needed for a freer exchange of ideas; for ways to realize greater accountability and thus the establishment of real bases for trust; and, ultimately, for more creative and meaningful explorations of the natural world.

By way of examples, we offer three areas of particular interest. First, we turn to what has become a foundational area of scholarship - the field of Victorian studies of science and popular culture-where a critical mass of research on print popularization has clarified our understanding of the "birth" of both professional science and the popularization of science. Here also, we see the powerful effects that resulted from popularizers' literary strategies for communicating ideas about nature both to specialists and to lay readers. We also point out areas where questions that are just beginning to be asked introduce topics that deserve greater attention from practitioners and policy makers. One such area is that of science on display in museums. We suggest that studying emergent institutional practices at large, complex sites, including those such as late twentiethcentury science museums, shows promise for clarifying the relationship between the medium and the message of popular science, especially with regard to science education. Finally, moving from site-specific material to theme-specific material, we consider how attending to seemingly two-dimensional portrayals of science in popular culture can provide critical insights about exchanges across the scientist/nonscientist divide-and how if scientists ignore the arguments to be found there they exacerbate a sense of disenfranchisement on the part of the public in regard to science.

\section{VICTORIAN STUDIES OF SCIENCE AND POPULAR CULTURE}

For anyone interested in questions about the nature of science and popular culture, it should not be surprising that those who study the past would suggest: start at the beginning. For our purpose, "the beginning" means the nineteenth century.$^{10}$ It is true that in previous centuries the work of natural philosophers was embedded within a nexus that included high and low culture, that literary treatments of matters of natural philosophy had found a welcome place in the domain of polite culture (the drawing rooms and salons of

\footnotetext{
${ }^{9}$ Gregory and Miller, Science in Public (cit. n. 5), p. 88.

10 Like Anne Secord before him (see Anne Secord, "Science in the Pub: Artisan Botanists in Early Nineteenth-Century Lancashire," Hist. Sci., 1994, 32:269-315), James Secord has lamented "the diffusionist baggage borne by the term "popular science," and he argues that to periodize it is as problematic as studying it across time and place: “To dump Johann Amos Comenius's Orbis sensualium pictus (1658), Camille Flammarion's Astronomie populaire (1879), and Stephen Hawking's Brief History of Time (1988) in a single genre surely conceals more than it reveals. 'Popular science' is not a thing that comes into being at a particular moment or period; it is not appropriately seen as an emergent category." James Secord, "Knowledge in Transit," Isis, 2004, 95:654-672, on p. 670.
} 
the wealthy and learned elites of the Western world), and that discussions of scientific principles could be found in practical works. But there was nothing in previous centuries that could match the scale of the nineteenth century's proliferation of forms of scientific life. ${ }^{11}$ Whether measured in terms of the increasing pace and fecundity of scientific activity, the numbers of people devoted to its development, or the creation of new possibilities for widespread readerships on scientific topics-due to increases in literacy and decreases in publishing costs in the steam age, which made books, magazines, and other printed matter available in ways never before possible - the nineteenth century was a watershed. The professional world of science and the popularization of science to a variety of publics emerged together within this common environment; before 1900 there was no professional science from which we would distinguish popular science. ${ }^{12}$

In the Victorian period - as today - both popular media outlets and media literacy were undergoing unprecedented explosions: the nineteenth century's new pamphlets and newspapers have given way to the twenty-first century's Web sites and internet blogs. Indeed, the nineteenth century experienced a communications revolution of the same intensity as the communications revolution we are now undergoing as a result of the computer. Increased engagement with-rather than dismissal of - these developments might encourage scientists to see how making their knowledge of nature accessible to a broader range of stakeholders could both increase science literacy on the part of the public and lead to a better understanding of the public on the part of scientists.

Take, for example, the cultural commotion caused by the appearance of Vestiges of the Natural History of Creation, an anonymous popular work on evolution that appeared fifteen years before Darwin's Origin of Species. During the twentieth century the existence of Vestiges was mostly a matter for footnotes within historical scholarship, despite the shock waves the book had sent out in its historical era, both for the evolutionary sentiments it espoused and for the fact that it dared to bring scientific knowledge outside of specialist domains and into the public sphere. James Secord, in Victorian Sensation: The Extraordinary Publication, Reception, and Secret Authorship of Vestiges of the Natural History of Creation, gave this emergent episode in popular science its due some 150 years later, drawing kudos from scientists and historians for taking popular culture seriously. Secord described his own book as "an experiment in a different kind of history." By focusing on the reception and the various readings of Robert Chambers's popular book on evolution, this experiment demonstrated the efficacy of recasting science's intellectual history "by looking at the basic material products of cultural life and drawing upon techniques developed for studying ordinary action." ${ }^{13}$ In placing analysis of the scientific reception of Chambers's book on a par with analysis of its popular reception (accessed

\footnotetext{
${ }^{11}$ See Ian Hacking's use of Wittgenstein's idea of "forms of life" to describe varying, overlapping modes of scientific practice in Representing and Intervening: Introductory Topics in the Philosophy of Natural Science (Cambridge: Cambridge Univ. Press, 1983), p. 215.

${ }^{12}$ Two good places to start for overviews of the voluminous work on Victorian science and popular culture are Bernard Lightman, ed., Victorian Science in Context (Chicago: Univ. Chicago Press, 1997); and Louise Henson et al., eds., Culture and Science in the Nineteenth-Century Media (Aldershot: Ashgate, 2004). For a more recent historiographic overview, with special attention to print culture, see the introduction to Lightman, Victorian Popularizers of Science: Designing Nature for New Audiences (Chicago: Univ. Chicago Press, 2007).

${ }^{13}$ James Secord, Victorian Sensation: The Extraordinary Publication, Reception, and Secret Authorship of Vestiges of the Natural History of Creation (Chicago: Univ. Chicago Press, 2000), pp. 518, 520. When seeking evidence that Victorian studies of science and popular culture have "arrived" in the historiography of science, one need look no further than the History of Science Society, which in 2002 awarded Secord its highest scholarly publishing honor, the Pfizer Prize, for Victorian Sensation; for the citation see http://www.hssonline.org/society/ awards/2002/citations/pfizer.html (accessed 24 Sept. 2007). The critical response can be sampled from reviews
} 
through circulation and sales records, as well as accounts from archives, newspapers, and memoirs of personal "encounters" with the book), Secord made explicit the mutual permeability of "scientific knowledge" and "popular knowledge." 14

Secord's insistence that "mundane considerations ... need to become the bedrock for literary and intellectual history" implies that even "the most abstract ideas about nature"such as evolution-should be reexamined from the perspective of communication: where, how, and why knowledge of ideas about nature was conveyed and circulated. "What once made sense as 'the Darwinian Revolution," Secord writes in Victorian Sensation, "must be recast as an episode in the industrialization of communication and the transformation of reading audiences." Elaborating later on this same argument, he suggested that

an approach grounded in communication opens up the possibility of integrating accounts of technical, specialist aspects of science with their wider uses. ... It is often thought, for example, that the history of the scientific book involves looking at publishers, binders, readers - anything but the actual words on the pages being produced. But this is simply not the case, or at least certainly should not be. Everyone knows Marshall McLuhan's famous slogan, "the medium is the message"; but it is simultaneously true that messages are the medium: they are what defines a communications technology. ${ }^{15}$

Thus while historians of science might take from Secord's work an imperative to pay attention to the readers (as well as the writers) of scientific books, another lesson suggested by his retelling of the Vestiges episode-and one arguably of greater importance for scientists - is that laboratory specialists could better communicate the key ideas of their research with their publics if they attended as carefully to the relationship between form and content in their public interventions as did the earlier popularizers.

In the middle decades of the nineteenth century the then-anonymous author of Vestiges, and the thousands of readers who responded to the book, put the question of "Who speaks for science?" forthrightly on the public agenda. This question continued to resonate as a new generation of scientific practitioners began to create professional spaces for what we would come to know as the scientific enterprise. Scientists argued that it was professionals who spoke for science, as a matter of right born of expertise. But many other Victorian authors believed that what constituted "the scientific community" consisted of more than professionals, and that this rightly should be understood in liberal rather than constricted terms, and they set out precisely to push back at the boundaries being set by professionals. As Bernard Lightman argues in his essay " "The Voices of Nature': Popularizing Victorian Science," popularizers responded to the kind of interest in the natural world demonstrated by the public that engaged with Vestiges by creating numerous works that "continued to give the public a sense that they participated in the production of knowledge. The publishing success of popularizers indicates that there was resistance to the claims of professional scientists to provide the only legitimate voice of nature and to their attempt to secularize science." To see that success, consider the following startling statistic comparing two works in natural history, the first from 1858, the second from 1859: in its first ten years of being a best-seller, J. G. Wood's Common Objects of the Country sold

of Secord's book: David Oldroyd, "The Book That Rocked the Victorian World," Nature, 2001, 409:285; and David Hull, "The Great Success of a "Foul Book," Science, 2001, 291:833-834.

${ }^{14}$ E.g., the geologist Adam Sedgwick's vitriolic public review of Vestiges is contrasted with his engaged scrawlings in the margins of his personal copy; see J. Secord, Victorian Sensation, esp. Ch. 7.

${ }^{15}$ Ibid., p. 4; and J. Secord, "Knowledge in Transit" (cit. n. 10), p. 667. 
close to sixty-four thousand copies; Darwin's Origin of Species, in comparison, sold ten thousand within that same span of time. ${ }^{16}$

Where Secord displayed the benefit of excavating the range of relations that radiated from one popular sensation, Lightman has taken on the examination of more than thirty popularizers and their diverse efforts to reach a public audience, providing a radically different picture of the "history of science" than has been conveyed through looking at professional scientists alone. Lightman's research demonstrates that "the popularizers of Victorian science not only provided alternate voices to be heard by the reading public, but also offered different ways of speaking about nature," and it is in these different ways that lessons in communication might be most straightforwardly understood by present-day scientists as well as historians. In Lightman's view, what distinguished the successful popularizers is that they were storytellers who devised compelling narratives that allowed them to expound on the larger philosophical questions embedded within scientific discoveries. They worked especially with the "traditions of natural history, with its emphasis on the anecdote, on observation, and on the experiences of the observer." They experimented with formats, such as the "narrative of common things" where the everyday was revealed in all its fascination (as with Wood's Common Objects), or the "evolutionary epic" - the style pioneered by Chambers in Vestiges - which "allowed popularizers to range across astronomy, geology, biology, and many other sciences, [and where] the idea of evolution became the key to finding the connections between the various branches of scientific knowledge." ${ }^{17}$ Popularizers provided syntheses, synoptic overviews, and more: at heart, as storytellers who engaged with questions of meaning as well as providing information, they brought the larger public into communication with the search for natural knowledge by incorporating their hopes and dreams and fears and speaking directly to their experiences. ${ }^{18}$ Popularizers were part of an ongoing cultural critique in which the question of "Who speaks for science?" was answered: "All of us." Contemporary scientists interested in engaging their various publics thus have much to learn from histories showing how narrative strategies can shape both understanding of and enfranchisement in the scientific enterprise. Given the trends toward increasing specialization and multidisciplinary collaborations in the laboratory, this lesson in communication is as pertinent to experts who need to reach out to other nonexpert scientists as it is to scientists who seek to reach out to lay publics.

\section{SCIENCE ON DISPLAY: POPULARIZING NATURE IN MUSEUMS}

Another area that has been claimed by historians of science but not fully explored for its potential to illuminate popular science is the study of science museums. As Samuel Alberti has noted, the many histories of science in museums produced in the last two

${ }^{16}$ Bernard Lightman, “The Voices of Nature': Popularizing Victorian Science,” in Victorian Science in Context, ed. Lightman (cit. n. 12), pp. 187-211, on p. 191; and Lightman, Victorian Popularizers of Science (cit. n. 12), p. 492.

${ }^{17}$ Lightman, “"Voices of Nature,"” p. 191; and Bernard Lightman, "Popularizing Science: Nineteenth-Century Origins, Strategies, and Syntheses," unpublished MS, prepared for the May 2007 Woods Hole conference.

${ }^{18}$ Their strategy, upon reflection, is not unlike that recommended by James Secord for historians of science seeking "to combat what might be called the 'Sobelization' of the history of science, with the subject being carved up into heroic sound-bites modeled on Dava Sobel's phenomenally successful Longitude: The True Story of a Lone Genius Who Solved the Greatest Scientific Problem of His Time (1995). We need unifying narratives and a sense of large connections, even if they are not the old-style Cinemascope stories offered in the confident days of the Cold War." See J. Secord, "Knowledge in Transit" (cit. n. 10), p. 656. Cf. David Philip Miller, "The Sobel Effect," Metascience, 2002, 11:185-200; and John Gascoigne, "'Getting a Fix': The Longitude Phenomenon," Isis, 2007, 98:769-778. 
decades draw on "richly detailed histories of specific institutions [that] have been supplemented by broader studies of the museum's role in society." These accounts have been invaluable for understanding the ambitions and achievements of particular scientists working in museums, as well as how museums more generally have come to be at the contemporary cultural crossroads of scientific and public interests. At the same time, because they often ignore the educational functions of so-called new museums - functions identified as fundamental for the last hundred years by stakeholders as varied as scientists, elementary school teachers, parents, and education policy makers-historians of science have missed an important chance to understand how these complex institutions are important, if contested, sites for communicating ideas about nature and the process of science to diverse publics. ${ }^{19}$

Of special interest is how heated conversations about the relative role of public education and research in American science museums became in the years between 1940 and 1970. ${ }^{20}$ Two competing models emerged during this period, best epitomized by the views of Bradford Washburn, longtime director of the Boston Museum of Science (1939-1980), and Frank Oppenheimer, founder and director of San Francisco's Exploratorium (1968-1984). Washburn, a nature photographer and explorer, initially undertook a mission to transform a dusty, unpopular museum of natural history into a modern science center - as he put it in many annual reports, to create "a museum for everybody." In the process he crafted a series of new displays at the Museum of Science around a simple educational philosophy: "Exposure is the important thing!" By increasing the number of interactive displays and committing to rotating displays that highlighted current advances in all the sciences, Washburn believed he could teach visitors to be inspired by science and technology. Later, in the wake of Sputnik, he further suggested that exposure of young children to science through science museums could work to "create an attitude of appreciation and understanding of science" that would help the United States overcome any future scientific manpower issues. ${ }^{21}$

The physicist Frank Oppenheimer turned to museums from a second career in high school science education because he saw "an increasing need to develop public understanding of science and technology ... to bridge the gap between the experts and the layman." Oppenheimer argued that achieving this goal would be possible only in a physical place (apart from the classroom) with what he called "a laboratory atmosphere"- a place where people of all ages, from all walks of life, could enter and "become familiar with science and technology and gain understanding by controlling its props." "Explaining science and technology without props," Oppenheimer wrote in 1968, "can

${ }^{19}$ Samuel J. M. M. Alberti, "Objects and the Museum," Isis, 2005, 96:559-571, on p. 559. See also Sally Gregory Kohlstedt, “'Thoughts in Things': Modernity, History, and North American Museums," ibid., pp. 586-601. On museums as complex sites and the importance of place see Sophie Forgan, "Building the Museum: Knowledge, Conflict, and the Power of Place," ibid., pp. 572-585. All three of these pieces were part of a Focus section on "Museums and the History of Science."

${ }^{20}$ Victoria Cain and Karen A. Rader, "From Natural History to Science: Display and the Transformation of American Museums of Science and Nature, 1930-1955," paper presented at the Manchester Museum workshop "Nature Behind Glass: Historical and Theoretical Perspectives on Natural Science Collections," Sept. 2007.

${ }^{21}$ Bradford Washburn, "A Metropolitan Climate for Education: Our Community Responsibility," speech dated 18 Feb. 1958, Box "1958," Folder "B.C. Seminar," Bradford Washburn Papers, Boston Museum of Science Library. Before the launch of Sputnik, Washburn wrote to Massachusetts senator John F. Kennedy, seeking support for an application he made to the U.S. State Department to visit Russian museums during a tour of Europe; the quotation pertaining to Washburn's educational philosophy is from his personal notes of this trip. See Bradford Washburn to John F. Kennedy, 20 May 1957, Box "1957-58," and "Trip Notes," Folder "European Trip 1957”: Washburn Papers. 


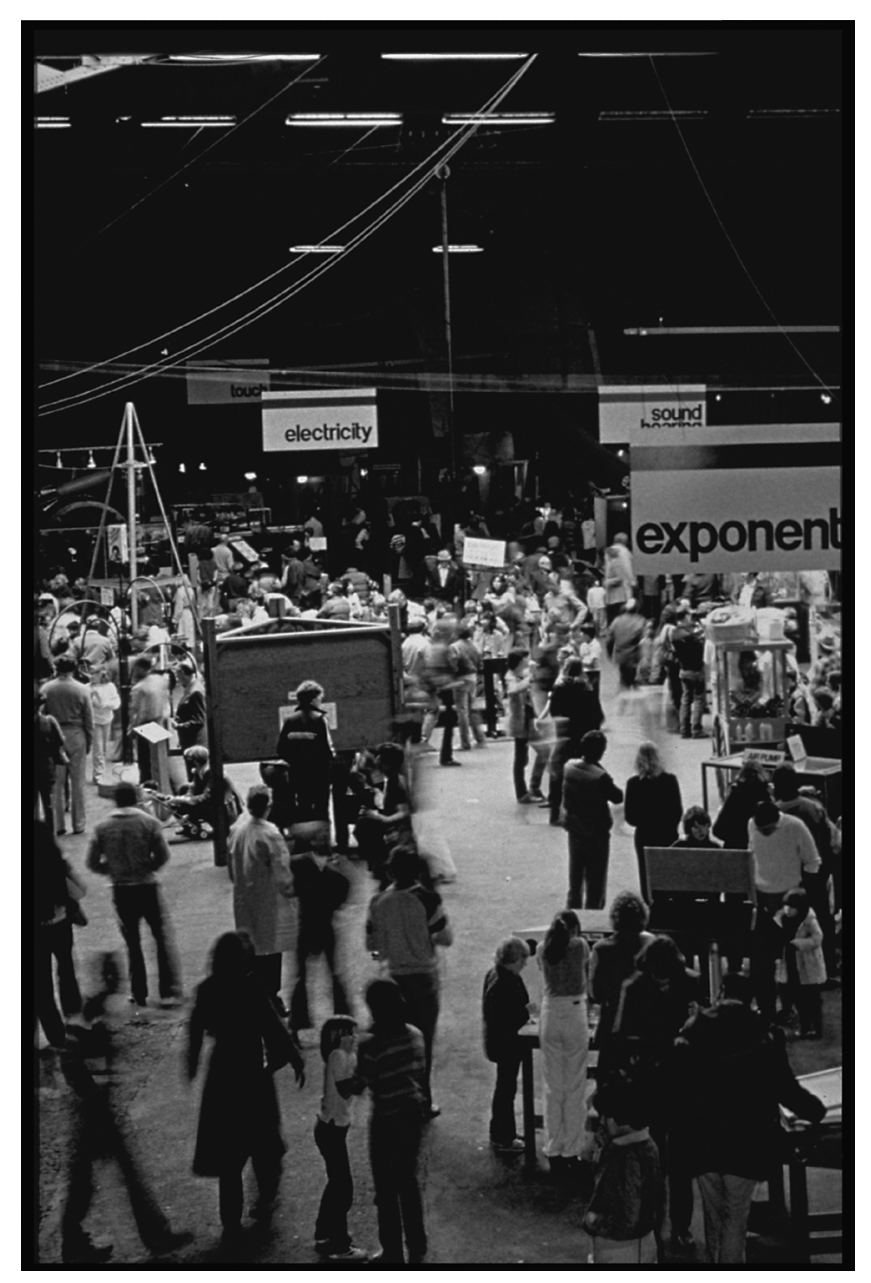

Figure 1. Visitors at the Exploratorium in the 1980s, when there were six hundred different exhibits on the floor. For director Frank Oppenheimer, the free-flowing, visitor-centered style of the Exploratorium epitomized his ideal for the science museum: "A museum ... should be a place where people come both to teach and to learn. .. . Above all it should be honest and thus convey the understanding that science and technology have a role which is deeply rooted in human values and aspirations." Frank Oppenheimer, "Rationale for a Science Museum," Curator, 1968, 11:206209, on p. 209. Source credit: Nancy Rodger, (c) Exploratorium, www.exploratorium.edu.

resemble an attempt to tell what it is like to swim without ever letting a person near the water." Displays at his Exploratorium epitomized the ideal that genuine scientific education could come only through "non-coerced" experiment (see Figure 1). Oppenheimer argued in a 1972 American Journal of Physics essay that the Exploratorium was a "playful museum"; his institution would "respond to the criticisms and the tenor of its times" by providing opportunities for its visitors to "become involved in their own [science] education process [in ways] that are difficult to achieve in school classrooms or through books, films, or t.v. programs." This "everyman his own scientist" pedagogical philosophy manifested itself at the Exploratorium in two ways: in exhibits with which visitors could easily interact and conduct miniexperiments and in a nonlinear exhibit arrangement that encouraged free choice about how to 
move through the museum (Oppenheimer talked not of making visitors "behave" but of designing the space in ways that "relieve the visitor" of any "obligations").22

Debates over what constituted effective science museum displays in this period thus both reflected and contributed to ongoing cultural conversations about the role museums would play in shaping relations between sciences and their publics. While American citizens increasingly frequented science museums, leaders and policy makers asked whether and how these institutions could be held accountable for their public role: should they be responsible for recruiting a new generation of scientists and engineers, or were their missions better conceived in terms of directly training a scientifically literate citizenry in knowledge of natural phenomena? Reconstructing this conversation provides a deeper understanding of the problem of popular science in museums-because Washburn's and Oppenheimer's models each conceived of what counted as "doing" science differently, each created a different array of possible relations between scientific practitioners and their publics. For the historian of science, the complex interaction of forces responsible for the realization of science museum displays suggests that it will not be enough to tell the story of how particular museums functioned as institutions of science. Rather, we need (to paraphrase Secord) analyses of the science museum that reflect its role as both the medium and the message of popular science. For contemporary scientists, such historical awareness would provide new tools for thinking about what constitutes meaningful public engagement through museums. More nuanced understanding of these complex historical sites will surely be important for practicing scientists, whose partnerships with museums continue to increase. ${ }^{23}$

\section{THE "INTELLECTUAL COMMONS" OF POPULAR CULTURE: LISTENING TO THE PUBLIC}

Moving beyond models, looking more closely to the history of how knowledge about nature has actually circulated among various publics and various professional worlds is equally essential for those scientists interested in developing practices that have the goal of engaging a participant public. A different approach from the deficit or diffusion models would be to take the sphere of popular culture as constituting an "intellectual commons" where something much more like multisided conversations about scientific topics take place, even if they do not proceed in the orderly, organized fashion of the specialized norms of professional discourse. Marked instead by heterogeneity, dispersion, and contradictions, this intellectual commons represents a means by which various publics can, in their turn, seek to engage scientific professionals in conversation-even if such unautho-

\footnotetext{
${ }^{22}$ Frank Oppenheimer, "Rationale for a Science Museum," Curator, 1968, 11:206-209, on pp. 207, 206; and Oppenheimer, "The Exploratorium: A Playful Museum Combines Perception and Art in Science Education," American Journal of Physics, 1972, 40:978-984, on pp. 978, 980.

${ }^{23}$ During discussions of the Smithsonian National Museum of Natural History's Five-Year strategic plan in 2005, the National Science Foundation's Rita Colwell noted that partnerships between museums and scientists had been increasingly supported by NSF over the last several decades, especially through its informal education program. Colwell argued: "Museums play the unique role of acting as the bridge between the public and the scientists and engineers. They provide an educational venue accessible to everyone - and they provide an educational experience covering an amazing breadth of subject matter." See "Dr. Colwell's Remarks, 10/30/03," http://www.nsf.gov/news/speeches/colwell/rc031030smithsonian.htm (accessed 24 Sept. 2007). Another policysanctioned area of expanded collaboration between academic science units and museums has come through the adoption of NSF review criterion 2 ("What are the broader impacts of the proposed activity?"), although precise data documenting the nature and scale of this phenomenon are difficult to collect. See J. Britt Holbrook, "Assessing the Science-Society Relation: The Case of the U.S. National Science Foundation's Second Merit Review Criteria," Technology in Society, 2005, 27:437-451.
} 
rized discourse has largely been disregarded by experts as having little meaning (or as being at worst in error and at best distressingly incomplete).

In fact, one of the most frequently occurring themes expressed within popular culture is unease with the idea of scientific elites withdrawing to private spaces beyond public contact. This theme is one that hearkens back to the formative period of professionalization that scholars of Victorian science have studied - think of the warning notes struck by such figures as Mary Shelley's Dr. Frankenstein, or Robert Louis Stevenson's Dr. Jekyll, or H. G. Wells's pair of doctors from The Invisible Man and The Island of Doctor Moreau - and continues on today in a variety of literary and cinematic genres in which the "mad scientist" image still resonates. What has been less well attended to are those instances where popular culture has offered suggestions for corrective measures-not necessarily through direct argument but, rather, by providing counternarratives that draw on images that are just as familiar as the cautionary ones. One example is the creation, circulation, and validation of ideal images of "the intimate scientist" to offset conventional images of the disciplined objectivity of the detached and neutral scientific worker who exists only within the confines of the laboratory.

Here, someone like the American horticulturist Luther Burbank (1849-1926) figures into a reconstruction of a forgotten legacy of counternarratives: Burbank is little noted today, yet for several generations, beginning with the turn of the twentieth century, he was one of the most famous scientific figures in the United States (and known throughout the world). Among the most resonant aspects of the Burbank stories that were carried in newspapers and mass-market magazines were the facts that he was a scientist who worked at home (his plant experiments took place on his own grounds), that he was accessible to the ordinary people who beat a path to his door, and that he was held to have become "a partner of Nature"- that is, one whose investigations had all led him "away from the idea of a dead, material universe ... to that of a universe which is absolutely all force, life, soul, or thought, or whatever name we may choose to call it." ${ }^{24}$

Burbank's potency as an image of the intimate scientist began to lessen by the 1950s, but new media variants arose to carry that image forward. One example appeared on American television screens on 20 March 1957 in the form of "Dr. Research," a character created by renowned film director Frank Capra as the star of Hemo the Magnificent, a science documentary on the physiology of blood. Capra expressly stated to his sponsors at Bell Telephone that "one of the objectives of this program is to show that science is an integral part of the lives of everybody, and not just an esoteric pursuit of a select few in ivory towers who are indifferent to the laws of God and country." ${ }^{25}$ Dr. Research was meant to personify just this sentiment: played by Frank C. Baxter, a University of Southern California English professor who was known to the television-viewing public through his popular programs on Shakespeare and English literature, he is an affable,

\footnotetext{
${ }^{24}$ Pandora, "Knowledge Held in Common" (cit. n. 3), p. 506. For background regarding the circulation of images such as Burbank's in mass-market magazines see Marcel LaFollette, Making Science Our Own: Public Images of Science, 1910-1955 (Chicago: Univ. Chicago Press, 1990).

${ }^{25}$ Hemo the Magnificent, directed by Frank Capra for Bell Science, 54 minutes, originally shown on CBS Network in 1957, rereleased by Rhino Home Video in 1991. On Hemo and Capra's other scientific documentary work see James Gilbert, "Almost a Message from God Himself," in Redeeming Culture: American Religion in an Age of Science (Chicago: Univ. Chicago Press, 1997), pp. 199-223; Capra's objective is quoted on p. 210. Hemo won its rating period, against NBC's Kraft Theater and ABC's Ozzie and Harriet (ibid., p. 216), and it would live on after its television showing; sixteen hundred color prints of Capra's science documentaries circulated throughout schools, churches, and clubs in the United States and Canada in the following decades (ibid., p. 223).
} 


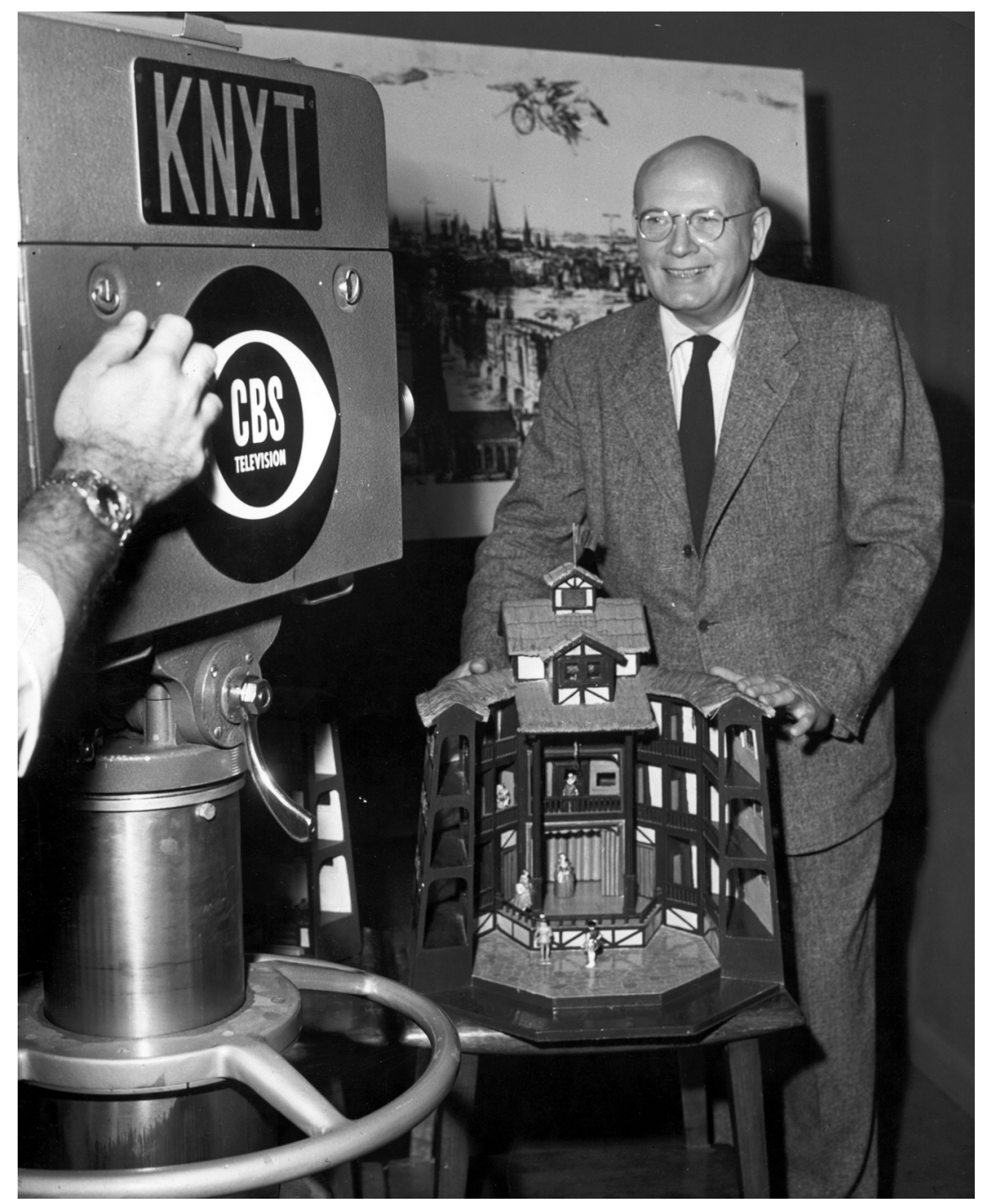

Figure 2. Echoing a key theme in Frank Capra's Hemo the Magnificent-that the humanities and science were one- "Dr. Research" was played by an English professor known to television audiences as an authority on Shakespeare. Source credit: University of Southern California.

grandfatherly guide who is as relaxed in speaking with nature itself-in the form of a set of whimsical cartoon characters-as he is in communicating with the viewing audience (see Figure 2). ${ }^{26}$ This feat is even more notable given that a major thread of the cinematic conversation is about what we would see today as an incendiary topic: the relation of science and religion. Attentive and patient with the questions that were posed by his cartoon figures about the origins of life, Dr. Research reveals that he has little use for a merely materialistic universe, even as he has the utmost respect for the pursuit of scientific

${ }^{26}$ On Baxter see Gilbert, Redeeming Culture, p. 365 n 34; and his biographical paragraph in the section on "Early Faculty Notables" at the University of Southern California Faculty Portal, http://www.usc.edu/academe/ faculty/especially_for/faculty/early_faculty_notables.html (accessed 22 Oct. 2007). 
knowledge. The focal sequence in Hemo is Dr. Research's tracing of the evolution of life forms from the first one-celled creatures in the sea to more advanced animals emerging from the ocean onto the land, until humans themselves evolved. He assuredly touches on the connections between evolutionary science and a divine plan: the composition of our life-sustaining blood, the professor explains, is essentially the same as that of the primeval sea that first sustained life in its simplest form. Thus, through Capra's storytelling expertise, Dr. Research offers an interpretation of hard scientific facts that offers room for spiritual mystery and wonder, presenting (in comparison with earlier Victorian archetypes) another exemplar of a scientist who is "a partner of Nature." The experiential, epistemological, and metaphysical values carried by such depictions can be powerful precisely because they subvert more disciplined and restrictive images of science simultaneously circulating within the intellectual commons of the vernacular.

\section{CONCLUSION}

Almost without fail, since the nineteenth century-when both the professionalization and the popularization of science occurred-scientific elites have chosen to see themselves in relation to the public in the flattering light cast by the diffusionist and deficit models we touched on in the introduction to this essay. There has been a significant amount of investment in the "common sense" of these models in terms of projecting symbolic authority, establishing pedagogical practices, and creating habits of engagement with the media. These investments have resulted in forms of communication that are intended to benefit members of the public by placing them on the receiving end of a relay system for conveying scientific information but are not designed to engage them as participants. If the public has too often been a distant end point in the thinking of scientific investigators, within the intellectual commons of popular culture it is a starting point and a mediating point and thus also part of the scientific community—a view that explicitly rejects the idea that the conversation over science should be one-sided.

Of course, conversations that are one-sided are not really conversations at all. True communication, as Gregory and Miller observe, "is a process of negotiation: it is one of a mutual getting to know." In large part, if the public is willing to participate, and if scientists choose not to engage in mutual conversation, the public will continue on nonetheless as it has done in the past—viewing scientists as (in Christopher Frayling's pointed description) "bewigged judges in court—remote, out of touch, unconsultative, much given to pontificating and immune from criticism." ${ }^{27}$ On the other hand, many professional scientists seem to feel ill-equipped to engage with nonprofessionals, given the lack of exposure they have had to working with the public and the meager training they have had in seeing the world of science through the framework of the humanities, with its emphasis on the centrality of epistemologies, ethics, and cultural meanings. ${ }^{28}$

${ }^{27}$ Gregory and Miller, Science in Public (cit. n. 5), p. 247; and Christopher Frayling, Mad, Bad, and Dangerous? The Scientist and the Cinema (London: Reaktion, 2005), p. 226.

${ }^{28}$ For evidence of this discomfort see scientists' responses to Matthew C. Nisbet and Chris Mooney, "Policy Forum-Science and Society: Framing Science," Science, 6 Apr. 2007, 316(5821):56; cf. Earle M. Holland et al., "Letters: The Risks and Advantages of Framing Science," ibid., 31 Aug. 2007, 317(5892):1168-1170. Nisbet and Mooney's argument that scientists should consider audience when deciding how to "frame" the communication of their research results for the public has generated much debate on science blogs: see, e.g., Nisbet's own at http://scienceblogs.com/framing-science/2007/04/dont_be_a_dodo_bloggers_weigh.php (accessed 7 Oct. 2007). 
Can scientists and the public together become "partners of Nature," through a broader, more comprehensive, more welcoming vision of how to widen the circle of the scientific community? History of science demonstrates that this wider circle of participants has always existed, although not in ways that have resulted in productive communication. As we have seen, popular science and public understandings of science have constituted active interventions in the making and elaboration of scientific knowledge-whether through the establishment and elaboration of a thriving market in books on scientific topics for the Victorian public, or in the creation of hybrid institutions such as science museums, or in the interpretations of natural knowledge that circulate in mass-media venues like magazines, television programming, and other more ephemeral formats. These activities should be of interest not only for what they can reveal to us about the genesis and development and circulation of scientific facts—broadly understood-but for the questions they raise about who we are, collectively and individually, as members of a culture marked so decisively by the scientific enterprise: How is the scientific community defined, both in the past and in the present-and when and why are these definitions inclusive or exclusive? Have such definitions been, are such definitions now, beneficial for both parties? Is what we experience as the current relationship between scientists and the public an inevitable outcome of the nature of scientific investigation, or is it the result of choices that could have been otherwise? ${ }^{29}$

Such questions point inevitably to the fact that it is at the boundaries where the most tension arises - and where effective communication becomes all the more necessary, and difficult, to accomplish. The work of historians of science thus provides a crucial resource for professional scientists, and the tools of history of science offer an irreplaceable means for illuminating the dynamics in which the issues of science in public become enmeshed. The examples we have sketched of real-world experiences, and the analyses we propose for interactions between actual historical agents, enable deeper understanding of the publics with which scientists are trying to communicate, as well as the ways in which conventional depictions of "communication" fail to meet the need to engage the public in partnership. But historians of science offer more than this as well: not simply a critique of current conditions viewed through perspectives from the past, but the making available of perspectives from the past to envision new models of public engagement. A proliferation of such models is crucial, when what is at stake is nothing less than a truly democratic conception of our contemporary era in which the scientific imagination plays an ever-increasing role in our individual lives, our collective lives, and the lives of nations.

${ }^{29}$ The resonance with Ludwik Fleck is deliberate. Lightman reminds us that Fleck noted long ago, in Genesis and Development of a Scientific Fact (1935; Chicago: Univ. Chicago Press, 1981), that "popular" science provides the basis for scientific knowledge in each generation: Lightman, "Popularizing Science" (cit. n. 17). For a fuller exposition of this research see Lightman, Victorian Popularizers of Science (cit. n. 12). In "Knowledge in Transit" (cit. n. 10), James Secord also references Fleck and further argues that "in any historical study of science, that boundary ought to be a critical site for investigation" (p. 671). On the dynamics of boundary-work, an essential analysis is Thomas Gieryn, "Boundary-Work and the Demarcation of Science from Non-Science: Strains and Interests in Professional Ideologies of Scientists," American Sociological Review, 1983, 48:781-795; see also Gieryn, Cultural Boundaries of Science: Credibility on the Line (Chicago: Univ. Chicago Press, 1999). 